\title{
New Russian Legislation on Employment of Teleworkers: Comparative Assessment and Implications for Future Development
}

\section{目 Elena Gerasimova}

Head, Department of Labour Law and Social Security Law, Law Faculty, National Research University Higher School of Economics, Candidate of Juridical Sciences. Address: 20 Myasnitskaya Str., Moscow 101000, Russia. E-mail: gerasimova@trudprava.ru

\section{目 Tatiyana Korshunova}

Associate Professor, Leading Researcher, Institute of Legislation and Comparative Law under the Government of the Russian Federation, Candidate of Juridical Sciences. Address: 34 Bol'shaya Cheryomushkinskaya Str., Moscow 117218, Russia. E-mail: korshunovat@list.ru.

\section{目 Daria Chernyaeva}

Associate Professor, Department of Labour Law and Social Security Law, Law Faculty, National Research University Higher School of Economics. Address: 20 Myasnitskaya Str., Moscow 101000, Russia. E-mail: dchernyaeva@hse.ru

\section{Abstract}

The article presents in-depth study of the legislative logic and trends that have recently developed in Russian law in regard to foreign workers and teleworkers, both as separate categories and when these two characteristics meet in one person. The study gives a short introduction into the history of the phenomenon and formation of the terminology in this field and outlines recent amendments to the Labor Code of the Russian Federation in regard to these categories of employees, pointing out the deficiencies of new provisions and approaches and describing the legal consequences they entail. It is demonstrated that several important issues were omitted (or forgotten) in the process of drafting and that the previous rigid approach still persists in the Code. The study then addresses the omitted aspects of current telework regulation in Russia and suggests amending the Code with particular provisions introducing the principles of localization of the place of work and procedures for remote employment of foreign citizens and stateless persons, as well as provisions that would help teleworkers actively participate in collective labor relations and fully enjoy those trade union rights that they have been formally given. In the authors' opinion, the main problem with the current telework legislation is discrepancies and lacunae in the legal definitions of the core concepts in this field. These deficiencies may be attributed to the relatively recent appearance of telework in the Russian labor market. Consequently, the legislature has not yet acquired the experience to see all the significant aspects of this mode of work and regulate it adequately. At the same time, article regards the current situation positively enough to hope that the suggestions, ideas and approaches that they have considered in this paper will be used in the development of the Russian legislation in the field.

\section{에目 Keywords}

Russia; Labor Code; employment legislation; telework; transnational employment relations; collective labor rights; foreign workers. 
Citation: Gerasimova E., Korshunova T., Chernyaeva D. (2017) New Russian Legislation on Employment of Teleworkers: Comparative Assessment and Implications for Future Development. Pravo. Zhurnal Vysshey shkoly ekonomiki, no 2, pp. 116-129 (in English)

JEL: F66; J5; J61; K31; L96

DOI: 10.17323/2072-8166.2017.2.116.129

\section{Introduction}

Russia recently introduced a principal amendment to the Labor Code concerning remote work. Unfortunately, while amending the Code legislators did not take into account the transnational dimension of this type of work, such as foreigners working remotely for employers domiciled in Russia. Neither the Labor Code nor the Civil Code cover this category of workers, and no decisions either on what laws might be applicable or on hiring procedures and other legal particulars bearing on such employment relations have been made. This regulative lacuna with neither governmental guidelines nor substantial pragmatic solutions in place has naturally brought about enormous problems in legal practice.

The situation is aggravated by the rather rigid approach the Russian legislature chose for regulating remote work in general. The concept of remote work was defined in such a narrow way that transnational telework was excluded. Its incorporation into general provisions on remote work and/or development of special regulations for this specific category of labor has become more complicated as a result. It follows that no provisions on the rights and duties of remotely working foreigners have emerged, and no guarantees of equal treatment for them or provisions for their safety have been established. A separate problem with this category of workers lies in their participation in collective labor relations, including exercising their rights to organize and to bargain collectively. All this undoubtedly impedes development of the economy and hinders international cooperation. In this paper we would like to touch upon some of the most painful issues in this field that cause a disproportionate number of problems both in theoretical discourse and in practice.

\section{History of the Phenomenon and Terminology Applicable}

It is easy to see that both telework and its more traditional and time-honored relative homework (outwork) - are just two versions of the more general phenomenon of "remote work". The core feature of the latter is obvious from its name: job tasks are performed away from the employer's premises, and an employee doesn't physically present within those premises for all or most of the working hours. Usually, this also entails the absence of an immediate employer's control, at least in a physical sense.

However, in both legislation and scholarly writings this general nature is usually assigned to homework (outwork) itself. As a term, "outwork" is often mentioned as playing one of the two following roles:

an umbrella concept embracing both traditional work at or from home and telework as its modern analogi;

${ }^{1}$ See for instance Article 68 of the Slovenian Labour Code, etc. Some authors even use a term "telehomework" seeming to disregard the fact that generally speaking telework is not necessarily performed at home. see, for instance: Kleemann F. Telehomework: On the Temporal, Spatial and Social Disembedding of Work and Its Consequences: Inferences from the German Case. Paper presented at Conference "New Media and Everyday Life in Europe", 2003. Available at: http://www.lse.ac.uk/media@lse/research/EMTEL/Conference/papers/klee- 
a prototype of the concept of "telework"

Although it may not come to mind immediately, but one would hardly doubt that these current modes of work sprang basically from the same root of working at home, be it on a farm or in a workshop or in any other small home-based enterprise. The homework phenomenon itself was born long before the technological and informational revolutions, the oil and financial crises and modern traffic congestion. Initially such work was quite simple, low-skilled, lowpaid and often piecework.

\section{Old Homework Acquires New Meaning}

The main distinction of the new modes of homework (including telework) lies not so much in where an employee is located during working hours (whether "at home" or at an "employer's site", because these two can be actually the same place), but rather whether the place where an employee is located belongs to the employer and whether the employer or his authorized representatives can (and need to) exercise immediate "physical" control over the employee working there.

A new phase in the history of this phenomenon gave it new features. At the next turn of technological and societal development, production and services went beyond small localities to become bigger and as geographically dispersed as contemporary transportation and communication technologies would allow.

However, the more distributed the structure of an enterprise became, the more it cost to manage and maintain it, and in some cases the more it also cost for employees to get to their workplace. At some point the biggest employers faced direct and indirect costs so financially unreasonable that they began a search for new organizational approaches that were expected to provide cheaper production and decrease tension between employers and employees (trade unions) demanding more flexibility and deeper recognition of their personal needs.

The search brought two major solutions: (1) to transfer production units to the third (or even third-world) countries (to save on wages and compliance) and (2) to have work performed more or less remotely (to save on commuting and compensation for it) with no company units created where the employees' were located. Both options allowed an employer to have cheaper production while retaining control over the enterprise (either through overseas units or through new informational and communicational technologies).

It has been evident almost from the beginning that the bigger a country is, the more the issue of commuting becomes painful. This suggests that the size of a country may determine to a degree the emphasis put on "commuting" in the definition of the phenomenon. Thus, "telecommuting" is still a much more popular name for the phenomenon in the USA and China than in Europe 3 . However, many countries have recently borrowed either "telework"

mann.pdf (accessed: 1.03.2017); Bauer W. et al.Telehomework Case Study: Empirical Study on the Conditions and Effects of Telehomework. Working paper WP/95/58/EN. Dublin,1995; etc. Others distinguish traditional homework and "electronic homework" where the latter usually corresponds to what we now call "telework" see for instance: P. Jackson, J. Wielen (eds.) Teleworking: International Perspectives. From Telecommuting to the Virtual Organization. N.Y., 1998; etc.

${ }^{2}$ Huws U. The New Homeworkers: New Technology and the Changing Location of White Collar Work. London,1984; Tunnel S. Telecommuting: Homework for the Future. Journal of Computing Sciences in Colleges. Vol. 15. No. 3, pp. 119-127.

${ }^{3}$ One can easily confirm this through the Google search. However, there are also research works that touch upon this issue, see for instance: Kurland N., Bailey D. Telework: the Advantages and Challenges of Working Here, There, Anywhere and Anytime. Organizational Dynamics. Vol. 28, pp. 53-68; Qvortrup L. From Telework to Networking: Definitions and Trends /Teleworking: International Perspectives.... pp. 21-39; etc. There are also 
or "telecommuting" as a ready-made term, choosing the one that suits best their languages and business specifics. This is the case for Russia where "telecommuting" can be seen as hard to translate, while "telework" had been easily translated as early as in the $1990 \mathrm{~s}^{4}$ as "телетруд” (“teletrud”) or “телеработа” (“telerabota”), or rarely “дистанционный труд” (“distance work”) or “электронное надомничество” (“electronic outwork”).

Nevertheless, we see the control issue as still central to all these processes. Just as during the first industrial revolutions, business has increased the pace of its expansion in step with the development of the information and communication technologies (ICTs). The closer employers' control becomes possible, the more remote subsidiaries and workers become from the headquarters.

The main difference between our time and earlier ones lies in the relationship of structure and control. Many tools have become quite affordable for an average worker and much more portable or mobile. This has substantially decreased the need to stay on an employer's premises to do a job. Workers are no longer bound to the employer's location. In terms of structure this can be seen as a step backwards to the times of self-employed craftsmen working at home. The difference is that now it is the employer who sets tasks for the working man, while formerly it was a wholesaler or the market in general that determined what tasks would be undertaken.

However, in terms of the degree of control the current situation is obviously much more advanced. Now only ethics and law limit an employer's control rather than available technology. People are more concerned whether it is ethical and legal for an employer (or its representatives) to use hidden cameras in a workplace or read employees' e-mail messages than with how to implements such controls.

Therefore, while enterprise structures become increasingly loose and dispersed, the employer does not sacrifice control over the worker and the work process. The control may actually be even tighter.

\section{Telework: History of the Term}

In considering the history of telework as a term, some $\mathrm{e}^{5}$ start with mentioning $\mathrm{N}$. Wiener's legendary example ${ }^{6}$. He described an architect using a fax machine (then named Ultrafax) to remotely supervise a building process and thus replacing his physical commuting to the construction site with an "informational" one. However, as we all know Wiener did not actually give the process a special name. Others ${ }^{7}$ prefer to cite J. Nilles's exercise ${ }^{8}$ of putting together "telecommunications"

other terms some authors use as synonyms for "telework" or "telecommuting", sometimes with minor alterations in content and/or meaning: e-work, distributed work, electronic homework, work-at-home, flexiplace, etc. Some less popular terms (like "mobile work" or "virtual work") are rather controversial.

${ }^{4}$ See, for instance.: Kiselev I. Yu. Zarubezhnoe trudovoe pravo [Foreign Labour Law]. Moscow, 1998; Kiselev I.Yu. Novyi oblik trudovogo prava stran Zapada: proryv v postindustrialnoe obchestvo [New Image of Western Labour Law: Breakthrough to Postindustrial Society]. Moscow, 2003.

5 Westfall R. The Microeconomics of Remote Work / M. Igbaria, M. Tan (eds.) Virtual Workplace. Hershey, 1998, p. 256; U.S. Department of Transportation. Transportation Implications of Telecommuting. Wash., 1993, p. 4; etc.

${ }^{6}$ Wiener N. Human Use of Human Being: Cybernetics and Society. Boston, 1950, pp. 97-98.

7 Bailey D., Kurland N. A Review of Telework Research: Findings, New Directions, and Lessons for the Study of Modern Work. Journal of Organizational Behavior. 2002. Vol. 23, pp. 383-400;. Sullivan C. What's in a Name? Definitions and Conceptualizations of Teleworking and Homeworking. New Technology Work and Employment. 2003. Vol. 18, pp. 158-165; Siha S., Monroe R. Telecommuting's Past and Future: a Literature Review and Research Agenda. Business Process Management Journal. 1997. Vol. 12. No. 4, pp. 455-482.

8 Nilles J. Telecommunications and Organizational Decentralization. Transactions On Communications. 1975. Vol. 23. No. 10, pp. 1142-1147 or Nilles J. et. al. The Telecommunications - Transportation Tradeoff. N.Y., 1976, pp. 4-5. 
and "commuting" to create "telecommuting". Later this long term shortened to "telework" (presumably when not just the commuting became mostly electronic, but a substantial part of the work itself). However, it is obvious that both terms were ultimately derived (whether directly or through intermediary words like "telecommunications") from the ancient Greek tèle- that meant "far off", "remote in time or space". That takes us back to the initial idea of the phenomenon as above all a matter of "remote work" and makes speculation about the central role of ICTs in the "distinction between telework and other forms of decentralized work and work at home" 10 considerably less interesting.

"Telework" as a term definitely has more of "telecommunications" and ICTs in it then of the ancient têle-. More and more often it is not the remoteness that is emphasized but rather its "electronic" ("telecommunicational") nature. This conclusion is contradicted to an extent by the names given to the phenomenon in some other languages which do not include any references to ICTs but instead do include a term meaning "remote" and/or "distant" (distantly performed $)^{11}$. The remote nature of the work is accentuated by such terms more than the electronic mode in which it is performed.

However, it is still the control issue that matters. In fact an employee may perform the main part of his work on paper if she finds it handy and may do it not very far from the employer's place of business. She may find it convenient to work from the café on the ground floor of a business center with the employer's headquarters just a couple of floors above. The primary consideration is that the employee is allowed to work apart from the formal office place and is free to move around it and beyond (more like a self-employed person), rather than that she works with ICTs and/or far from the employer.

\section{Conceptual Problems with Telework in Current Russian Federation Legislation}

Chapter 49.1 "On distinctive features of remote work of employees" of the Labor Code introduced in 2014 was meant to regulate all spatially dispersed employment relations. However, its conceptual framework strikingly lacks the consistency necessary for this purpose because it eliminates one of the two classical interpretations of "telework" (as remote work of any kind) and creates obstacles for the other (electronic) one.

The first issue arises from the very definition of "remote work" in Article 312.1 of the Labor Code which peremptorily describes it as only work for which ICT networks are used (and are used for communication between the employer and the employee on execution of a job). This puts "more traditional" telework not using these electronic technologies completely outside the scope of this chapter of the Code and leaves the parties to such relations with the old dilemma: either make them conform to the provisions on the obsolete "outwork" concept (Chapter 49 of the Labor Code) or conclude a contract for services that falls completely under the provisions of the Civil Code and provides almost no labor rights to the worker.

The second issue arises from the way in which definitions are arranged in the article 312.1 of the Code. Having given the definition of "remote work" itself, neither this article nor any of Chapter

${ }^{9}$ Oxford Dictionary of English. Oxford, 2010. Compare also: telemetry (measurements performed remotely), teleceptor (remote receptor), etc.

10 See also, for instance: Sullivan C. Op. cit. P. 160.

${ }^{11}$ Compare for instance: Russian “дистанционная работа" (“distance work” - Article 312.1 of the Labour Code), Bulgarian "работата от разстояние" ("work from a distance” - Article 107 of the Labour Code), etc. 
49.1 ever refers to this concept anywhere in the text. All the other provisions that introduce a desirable flexibility into these specific relations apply exclusively to "remote employees" defined as persons that have concluded an employment contract on remote work. This leaves no legal options for the parties to conclude a contract with a mixed nature, combining remote and traditional work which would permit the employee to couple periods of working remotely with sometimes being at the employer's premises in person. This is particularly problematic for a highly skilled workforce (and citizens of foreign countries in particular) operating in such a combined mode because the inability to take advantage of the provisions of Chapter 49.1 of the Code renders all its flexibility (regarding tracking working hours, record keeping, occupational safety and health requirements, etc.) automatically inapplicable. It is obvious that this approach (or possibly simple carelessness in the definitions and their application in the new provisions) has nullified all the easing in the requirements of the Labor Code that had been intended to help employers attract more highly skilled professionals from all over the world in order to facilitate national economic growth and technological development.

\section{Employment Issues in the Current Regulation of Telework in Russia}

The Labor Code of the Russian Federation ${ }^{12}$ (hereinafter LC) was amended in 2013 with a new Chapter $49^{1}$ that addresses remote work. Employees working remotely were granted a number of exemptions from the general rules applicable to hiring and execution of employment contracts so that the entire process is more modern, involves less paperwork and is less burdensome for the parties to an employment contract. For example, the parties were allowed to exchange documents in electronic form ("electronic documents") as long as they are authenticated with a so called "reinforced qualified electronic digital signature"13. They were also allowed to abstain from maintaining "work books"14 on employees and from including clauses on using various equipment, programs and technical tools that an employer may provide or recommend. A remotely working employee was also permitted to set his or her own work and rest regime, etc.

The Chapter also gives a formal legal definition of a so-called "remote employee" (distantzionniy rabotnik) which rests upon the definition of remote work itself. A person is considered to be a remote employee if he or she has concluded an employment contract on remote work, which in turn is defined as

12 Trudovoy Kodeks Rossiyskoy Federatsii [Labor Code of the Russian Federation] / SPS Consultant Plus

13 Both "electronic document" and "electronic digital signature" are formal legal terms defined in the legislation. Thus, "electronic document" is defined in Article 2 (11) of Federal Law No. 149-FZ of July 27, 2006 as "documented information represented in an electronic form, i.e. in a shape suitable for human perception with the use of computers and for transmission via information and tele-communication networks or processing in information systems". An "electronic digital signature" and its types are defined in Article 5 of the Federal Law No. 63-FZ of April 6, 2011 / SPS Consultant Plus.

${ }^{14}$ A book constituting a person's employment records that contains the name of every employer, the title and dates for every position the person has held, his or her profession or occupation, commendations from employers and other relevant information. Some scholars consider it to be a Soviet relic that should have been abolished as an unnecessary and useless burden for both employers and employees after Russian employment law adopted mandatory written employment contracts. At the moment most employers are still obliged to keep "work books" for every employee and can be fined for improper maintenance of them. See for instance: Chikanova L.A. Work Books. Labour Disputes. 2011. No. 9, p. 3; Philipova L.A. Work Books and Consequences of their Possible Abolition. Vestnik Nizhegorodskogo Universita. 2012. No. 3. Part 1, pp. 295-300, etc. 
"...performance of a labor function specified in the employment contract outside of a location of the employer, its subsidiary, its representative office, or other detached structural unit (including those located in another territorial locality, outside of a stationary workplace, territory or object which lies directly or indirectly under the employer's control) provided that informational and tele-communicational networks (including the internet) shared in common are used for the performance of this function and for the interaction between the employer and the employee on issues related to its performance as they communicate".

Such significant legislative innovations seemingly require an integrated approach taking all aspects of employment law into account. However, the new LC Chapter addresses only a narrow market segment that entails general performance of work duties with the help of shared informational and communication networks. It does not embrace regional company representatives or foreign citizens working from abroad for corporate headquarters located in Russia.

Basically the new LC provisions do allow establishing an employment relationship with foreign citizens working remotely. However, there are a few matters that it actually does regulate. For instance, if such persons do not come to Russia while employed by a Russia-based employer, their employer is not required to apply for a special permit ${ }^{15}$ to hire them. This is because such permits are provided only for "foreign employees", who are in turn defined in law in a way that is limited exclusively to foreigners physically present in Russia. Foreigners working remotely from outside Russia are automatically excluded from the "foreign employee" category because this is a formal legal concept defined in the legislation as "a foreign citizen temporarily staying in the Russian Federation and performing work activity in accordance with the established order"16. As long such a foreign employee does not stay in (or even enter) the Russian Federation at all, he or she is excluded from the statutory concept of a "foreign employee" and therefore does not create an obligation for his or her employer to comply with the statutory requirement to obtain a special permit to hire him or her.

Nevertheless, the situation changes radically if such a foreign citizen does come to Russia at least once or occasionally to do something related to his "employment contract on remote work" while generally still working abroad. At present the legislature has not arrived at any conclusion on this category of "remote employee". This category has been absolutely ignored in current Russian legislation; it seems not to exist for the legislature. All the legislative provisions on foreigners address only those who physically come to Russia (either with entrance visas or on a visa-free basis).

Another problem lies in the field of private international law. Many clauses of Federal Law No. 115-FZ - and not only those pertaining to "foreign employees" - rest upon the concept of "work activity of a foreign citizen" which itself is defined as "work of a foreign citizen in the Russian Federation on the basis of an employment contract or a contract for provision of services"17. However, Russian legislation does not provide any criteria for localizing work. Therefore one cannot say for certain when a certain piece of work has been performed "in the Russian Federation", or when it ceases, or when there has been no such thing. As a result, some

15 The major act regulating foreign citizens' status in Russia, Federal Law No. 115-FZ of July 25, 2002 (hereinafter Law No. 115-FZ) calls this permit a "permit for involvement and usage of foreign employees".

16 Article 2 of Federal Law No. 115-FZ / SPS Consultant Plus.

17 See for instance: Articles 2, 13, 13.2 - 13.6, 18-18.2, etc. of Federal Law No. 115-FZ / SPS Consultant Plus. 
clauses of Law No. 115-FZ cannot be interpreted clearly or in any reasonable fashion so that this piece of legislation actually falls apart.

It is certain that this issue does not have a single correct solution. Different legal orders use different approaches and sometimes regulate different categories of remotely working foreigners differently. Some of them consider work to be performed in the country when an employee has physically entered it and literally performs his or her job functions there. Other countries hold that work is to be considered as performed in the country where the employer resides and/or is registered. There are also other approaches we do not take up in this paper.

The Russian legislature seems to have passed over all these ideas. What it does mention is some general rules governing conflict between laws (in the private international law section of the Civil Code) and the concept of a "place of work". This concept might have been used in regulating telework by foreigners, but the legislature has consistently ignored its potential in this capacity.

Currently a "place of work" clause is mandatory for any employment contract (Article 57 of the LC). Contracts lacking this clause are considered invalid. Sometimes this clause also defines a type of contract (e.g. an "employment contract on domestic work" or an "employment contract on remote work"). If an employee is hired for work to be performed in some branch, subsidiary or other "detached structural unit" his or her "place of work" is to be specified by including the name and location of the subdivision.

Despite the obvious importance of the "place of work" concept for the interpretation and implementation of the laws on working foreigners, it lacks a formal legal definition. There have been several attempts to provide this in the theoretical literature ${ }^{18}$, but it has never found its way into formal legislation, either in general or specifically applicable to foreigners. Current university textbooks suggest interpreting this term as an employer and a territorial locality (district, area, region, etc.) where the employer is located and the employee is supposed to work $^{19}$. The "place of work" can be defined abstractly (by naming an organization that serves as the employer) or specifically (by giving an additional reference to the particular structural unit of the employing organization). The legislation also provides for further specification of the "place of work" down to a particular workplace ${ }^{20}$.

This definition engenders more problems than solutions. First of all, it does not correspond to the idea of the place where the work specified in an employment contract takes place. It is too general and too formal for that task, and it has neither an immediate relation to nor any clear connection with the place where the work agreed upon in the contract is actually performed. Second, it is too indefinite enough to clearly denote what it is supposed to mean in a regular employment relationship because it allows its application to an unreasonable variety

${ }^{18}$ For example, one of the acknowledged experts on Soviet labor law, K.M. Varshavskiy, wrote in regard to this issue, that "as a general rule, an employment contract's meaning is that an employer has a right to require work agreed upon from an employee not in any place where his or her or its whim dictates, but only within the limits of the enterprise, institution, or private household." (Varshavskiy K.M. Labour Law of the USSR. Leningrad, 1924. P. 84). Seventy years later a prominent Russian labor law scholar, Yu.P. Orlovskiy, defined the "place of work" more narrowly, stating that an employee may specify "the place of work". Such a specification would indicate a particular structural unit of an employer's enterprise where the employee wishes to work and operate through a particular mechanism. After such an agreement has been reached, the agreed upon specific place of work could be changed only upon agreement by the parties (Orlovskiy Yu. P. Commentary on the Legislation on Employment Contracts. Moscow, 1994. P. 22).

19 See: Trudovoe pravo Rossii [Labour Law of Russia]. A.M. Kurennoy (ed.) Moscow, 2008. P. 193.

20 See: Trudovoe pravo Rossii [Labour Law of Russia] S.Y. Golovina, M.V. Molodtzov (eds.) Moscow, 2008. P. 159-160. 
of places (that of the employer's legal address, the actual address where it operates in fact, the place[s] where it conducts its business), the registered address of residence of the employer if he or she is a physical person, on down to a particular workplace. This vagueness interferes with enforcement and prevents the parties to an employment contract from having a complete understanding of their responsibilities.

There is no special definition in the LC for the "place of work" concept that would apply to "remote work". The only passage that specifies something that could be relevant to remote work mentions the "place where the contract is concluded" (locus contractus) while the "place of work"-either in the sense of "the place where work is performed" (locus laboris) or in any of the other senses given in Russian legislation (locus domicilii, etc.) — neither stipulates special definitions for this case, nor provides any hints on where its physical and/or legal limits may lie.

\section{Collective Rights Issues in the Current Regulation of Telework in Russia}

\section{The Role of Social Partners in the Regulation of Telework}

Trade unions may play important role in discussions on the future evolution of teleworkers and in regulation of their work conditions. While trade unions in Europe have actively participated in debates about the future of labor in response to the globalization and digitalization of the economy as soon as these forms of labor appeared ${ }^{21}$, Russian trade unions have engaged much less in such discussions. International and European trade unions carefully scrutinized telework and worked on developing legal regulation for it at the international and national levels. They have provided abundant research ${ }^{22}$ on the nature of telework and its future from its early stages, including possible ways of regulating it and the role of trade unions in organizing teleworkers. They took an active part in designing the European Framework Agreement on Telework, 2002 (Telework Agreement) and its implementation ${ }^{23}$; and they now conduct research and participate in developing strategies for the future. ${ }^{24}$

In Russia the need to regulate the distinctive features of telework by law was first recognized publicly by the Russian Union of Industrialists and Entrepreneurs (RSPP) in a package of proposals for changes to the LC in 2009. At that stage trade unions vigorously opposed this proposal, but the main arguments were not against regulating telework but against such suggestions as prolonging working hours or giving employers right to unilaterally change employment contracts in reaction to changing economic conditions. Following that, the RSPP

${ }^{21}$ Telework in the European Union / European Foundation for the Improvement of Living and Working Conditions. 2010. Available at: http://www.eurofound.europa.eu/sites/default/files/ef_files/docs/eiro/ tn0910050s/tn0910050s.pdf (accessed: 26.02. 2017)

${ }^{22}$ Bibby A. Trade Unions and Telework. Available at: http://www.ine.otoe.gr/UplDocs/tekmiriosi/diafora/ european_trade_union/trade_union.pdf (accessed: 26.02.2017); Telework. Working Where One Would Like to Live. International Federation of Commercial, Clerical, Professional and Technical Employees. Available at: http://library.fes.de/pdf-files/netzquelle/01318.pdf (accessed: 01.03.2017); Telework-The New Industrial Revolution? TUC. 2001. Available at: http://www.tuc.org.uk/work_life/tuc-3664-f0.cfm (accessed: 1.03. 2017), etc.

${ }^{23}$ Implementation of the European Framework Agreement on Telework / Report by European Social Partners. 2006. Available at: http://www.ueapme.com/docs/joint_position/061010_telework_implementation_report_final.pdf. (accessed: 1.03.2017)

${ }^{24}$ Degryse C. Digitalization of the Economy and its Impact on Labour Markets. ETUI.Working paper 2016.02. 
no longer advocated that draft law as a whole and instead worked on its various components separately. The draft chapter of the LC on teleworkers that was brought to the State Duma as a separate draft law met with no objections from trade unions. There is no current research by trade unions into the working conditions of teleworkers and the way telework may further develop.

After the adoption of the Telework Agreement in the EU, its implementation was seen as a task for the social partners and in many countries resulted in various kinds of agreements. European social partner agreements at the national level were concluded in Finland, Spain, Latvia, the Netherlands, Germany, Sweden, Norway, Poland, Austria, etc. National or sectoral collective agreements came about in Belgium, France, Italy, Luxembourg, Greece, Iceland, Denmark and Sweden. There were also collective agreements for various companies as in Germany $^{25}$. In Russia there have been no attempts to regulate telework through collective agreements.

\section{Collective Rights of Teleworkers}

According to the Telework Agreement teleworkers have the same collective rights as workers on the employer's premises (clause 11). Hence, they should be able to participate and stand for elections to bodies representing workers under the same conditions as apply to workers on the employer's premises, and they should be included in calculations for determining thresholds for bodies representing workers in accordance with European and national law, as well as collective agreements or practices. They should be able to communicate freely with workers' representatives. Finally, "workers' representatives are to be informed and consulted on the introduction of telework in accordance with European and national legislation, collective agreements, and practices."

Russian law has no special provisions on the collective rights of teleworkers; therefore, all general norms apply to them. For teleworkers, including foreign teleworkers, there are no formal obstacles to or limitations on establishing or joining a trade union. There are also no limitations on creating trade unions in which both regular and teleworkers are members. At the same time no legal provisions guarantee their participation by remote means in trade union activities.

A few forms of worker representations are recognized today in Russia. The most popular form is a trade union. Under the Article 30 the Constitution of Russian Federation, adopted in $1993^{26}$, the positive and negative right of association is guaranteed. Russia has ratified Conventions of the ILO and other international treaties ${ }^{27}$, including the fundamental ILO Conventions on freedom of association No. 87 and $98^{28}$, and ILO Conventions No. 154 and No.135 ratified in 2010. The regulation of the right to join trade unions is contained in the LC and the Law on Trade Unions, their Rights and the Guarantees of their Activities of 1996

${ }^{25}$ Implementation of the European Framework Agreement on Telework. Report by European Social Partners. 2006. P. 7-11.

${ }^{26}$ Konstituziya Rossiyskoy Federatsii [Constitution of the Russian Federation]. Available at: http://www. constitution.ru/en/10003000-01.htm (accessed: March 1, 2017)

27 The International Covenant on Economic, Social and Cultural Rights, 1966; The International Covenant on Civil and Political Rights. 1966, etc.

${ }^{28}$ Freedom of Association and Protection of the Right to Organize Convention of 1948 (No.87), Right to Organize and Collective Bargaining Convention of 1949 (No. 98). ILO database of international labour standards Normlex available at: http://www.ilo.org/dyn/normlex/en/f?p=1000:1:0::NO (accessed: 26.02.2017) 
(hereinafter, Law on Trade Unions) ${ }^{29}$. According to the Law on Trade Unions everyone who has reached the age of 14 years and is performing a professional activity has the right to establish trade unions of their own choosing to protect their interests, as well as the right to join them, to engage in trade union activities, and to leave trade unions. Foreign citizens and stateless persons residing in Russia enjoy this right except for cases established by law. ${ }^{30}$

Trade unions represent workers at all levels of social partnership. More opportunities exist for worker representation at the plant level: there so called "other representative bodies" may be created by employees. In contrast with the Soviet era, workers' meetings and conferences are not considered a form of direct industrial democracy at the company level. In 2013 the Labor Code was amended with a norm that allows employers to create works councils; but in contrast with Europe, Russian works councils cannot be recognized as workers' representatives ${ }^{31}$. As already mentioned, no special provisions were developed in legislation to regulate representation of teleworkers, and regular legislation norms are applied.

Exercising this right de facto, however, runs up against certain legal and practical difficulties.

Because teleworkers are not on company premises and/or in a company's worker collectives, they are isolated from other employees and have less knowledge than regular workers of other employees' working conditions and problems. Organizing teleworkers into a trade union is more complicated for trade unions because of lack of contact and exclusion of teleworkers from the activities of worker collectives. Even finding contact information and reaching out to and speaking with teleworkers in order to build connections between them may become a problem when using traditional forms of organizing. Russian trade unions have so far not added organizing teleworkers to their agendas.

Exercising rights normally due trade union members may come into question for teleworkers. In trade unions with mixed membership (including both regular workers and teleworkers), organization of elections and trade union meetings can create problems. Although the Civil Code of Russia ${ }^{32}$ has allowed legal entities to hold meetings of their members by default ${ }^{33}$ since 2013, no provision has been made for meetings where members participate both in person and by default.

In some cases, employees have the right to elect what is designated by the terms "other representative" or "other representative body". According to Article 29 of the Labor Code, the interests of employees at the company level may be represented by primary trade union organizations or other representative bodies. Under Article 31 of the Labor Code, if there are no established primary trade union organizations within the company or if none of the primary trade union organizations acting at the company unites more than half of the employees of the employer and also is not authorized to represent the interests of all employees by the procedure stipulated by the Labor Code, then the interests of all employees may be represented by the "other representative (representative body)". The other representative may be elected by a secret ballot at a meeting or conference of workers. To organize the meeting of employees for the election of this "other representative", the same rules of the Civil Code mentioned above are to

${ }^{29}$ Federalniy Zakon o professionalnikh soyuzakh, ikh pravakh i garantiyakh deyatelnosti [Federal Act on Trade Unions, their Rights and the Guarantees of their Activity]. 12.01.1996. Sobraniye Zakonodatelstva Rossiyskoy Federazi (CZ RF). January 15, 1996. No. 3. Art. 148.

30 Article 2 of the Law on Trade Unions .

${ }^{31}$ Challenges and Opportunities for the Works Councils' System. R. Blanpain, N. Lyutov (eds.). Alphen aan den Rijn, 2013. pp. 183-201.

32 Civil Code of the Russian Federation. Part One. Federal Law of 30.11.1994 No. 51-FZ / SPS Consultant Plus.

${ }^{33}$ Article 182.1 of the Civil Code of the Russian Federation / SPS Consultant Plus. 
be followed, and that ends in the same legal question about the actual access of teleworkers to representation.

The form of organization of employee meetings is not widely discussed because the level of representation of teleworkers in Russia is low. Trade unions have not so far made an effort to organize teleworkers, and few teleworkers are unionized.

Perhaps the only trade union in Russia whose membership includes many teleworkers (but not only teleworkers) is IT Union, a trade union for IT specialists. ${ }^{34}$ This union is organized around the concept of mutual support to provide consultations and help, and it is not based at the level of companies as most Russian trade unions are. It has no signed collective agreements and has no influence on the working conditions of its members.

Nevertheless, the difficulties that teleworkers can face when they exercise their right to representation are being discussed by academics. Recognition of online meetings arranged as Skype or other VoIP conferences as the most convenient way for teleworkers to have access to representation has been proposed, and changes into the Labor Code have been suggested to accommodate this idea. ${ }^{35}$

Legal regulation of negotiations, collective consultations, and participation in the management of enterprises, as well as in resolution of collective labor disputes and exercise of the right to strike for teleworkers have no distinctive features. None of the Russian trade unions have ever brought up issues related to the implementation of these rights. However, we believe it is not because such issues do not exist, but rather because of the lack of experience with these issues at this point.

In some European countries telework and the conditions that apply to it are to be introduced only after consultations with worker representatives. In Belgium and Italy employee representatives are to be informed and consulted concerning the introduction of telework in an enterprise in the same way used to manage the social consequences of introducing other new technologies. In Poland, the conditions for using telework are to be agreed upon between the employer and the trade unions or other worker representative in the absence of a trade union. If the parties fail to reach an agreement on telework within 30 days of the employer's announcement of an intention to use telework, the employer is to arrange the conditions for using telework by taking into account agreements reached during discussions with worker representatives. In France and in the Netherlands, the works council or staff representatives are to be informed and consulted whenever some method for supervising telework is to be put in place.

The LC of Russia provides ${ }^{36}$ for consultation procedures in cases when an employer issues certain types of local normative acts and when employees are dismissed on certain grounds ${ }^{37}$, as well as when the employer takes certain management decisions. But the LC does not require consultations with workers' representatives on the introduction of telework; this question is to be decided solely by the employer. We consider telework to be an issue on which employee representatives should be consulted.

The employer is also under an obligation to take part in collective bargaining if worker representatives demand it and to sign a collective agreement at the plant level or higher levels

34 Trade union of IT-sphere specialists website. Available at: https://itunion.info/about (accessed: 23.02.2017)

${ }^{35}$ Nushtaikina K.V. Realization of Employees' Right to Social Partnership for Teleworkers. Vestnik Permskogo universiteta. 2013. No. 3, pp. 152-156.

36 Art. 372 and 373 of the LC / SPS Consultant Plus.

37 Russian Federation labor legislation contains a limited list of grounds for dismissal explicitly stated in the law. 
of social partnership (regional, interregional, sectoral or national) ${ }^{38}$. Teleworkers are free to participate in agreements at all these levels, but de facto no special agreements have so far been signed in order to promote the interests and rights of this category of employees. Similarly, no collective labor disputes, strikes or other types of collective actions have been organized by teleworkers or in their interests.

\section{Conclusion}

We have highlighted some legislative lacunas in the current regulation of telework in Russia, and one of the most obvious of these is the absence of any recognition of foreign teleworkers. We see this lacuna as the result of a somewhat hasty and consequently inconsistent enactment of the relevant clauses in the LC and related acts. We suggest not merely the introduction of more comprehensive regulation in this field, but also opening a discussion among Russian labor law scholars in order to develop a clear theoretical position within the academic community to address such problematic concepts as the "place of employment contract performance" and "place of work" taking into account broad international experience and Russian legal traditions.

As far as collective labor rights of teleworkers are concerned, we judge that in Russia they are currently regarded as a second-tier group of rights, which is currently much less developed in the legislation and only infrequently used by employees. We presume that the recognition and development of the collective labor rights of teleworkers is an issue that will be resolved in future.

\section{Deferences}

Bauer W., Maile M., Rebmann E., Glaser M., Glaser W. (1995) Telehomework Case Study: Empirical Study on the Conditions and Effects. Dublin: European Foundations for the Improvement of Living and Working Conditions, $286 \mathrm{p}$.

Bailey D., Kurland N. (1999) Telework: the Advantages and Challenges of Working Here, There, Anywhere and Anytime. Organizational Dynamics, vol. 28 (2), pp. 53-68.

Bailey D., Kurland N. (2002) A Review of Telework Research: Findings, New Directions, and Lessons for the Study of Modern Work. Journal of Organizational Behavior, vol. 23, pp. 383-400.

Bibby A. (1996) Trade Unions and Telework. Available at: http://www.ine.otoe.gr/UplDocs/tekmiriosi/ diafora/european_trade_union/trade_union.pdf (accessed: 1.03. 2017)

Challenges and Opportunities for the Works Councils' System (2013). R. Blainpain, N. Lyutov (eds.). Alphen aan den Rijn: Wolters Kluwer, pp. 183-201.

Chikanova L.A. (2011) The Work Books. Labour Disputes, no 9, p. 3.

Degryse C. (2016) Digitalization of the Economy and its Impact on Labour Markets. Working paper 2016/02. ETUI. Available at: http://www.etui.org/Publications2/Working-Papers/Digitalisation-of-theeconomy-and-its-impact-on-labour-markets (accessed: 01.03 2017)

Huws U. (1984) The New Homeworkers: New Technology and the Changing Location of White Collar Work. London: Low Pay Unit, 79 p.

Kiselev I.Y. (1998) Zarubezhnoe trudovoe pravo [Foreign Labour Law]. Moscow: Norma, 263 p. (in Russian)

Kiselev I.Y. (2003) Novyi oblik trudovogo prava stran Zapada: Proryv v postindustrialnoe obshchestvo [New Image of Western Labour Law: Breakthrough to Postindustrial Society]. Moscow: Intel-Sintez, 160 pp. (in Russian)

Kleemann F. (2003) Telehomework: On the Temporal, Spatial and Social Disembedding of Work and Its Consequences — Inferences from the German Case. Available at: http://www.lse.ac.uk/media@lse/ research/EMTEL/Conference/papers/kleemann.pdf (accessed: 01.03. 2017)

\footnotetext{
${ }^{38}$ Art. 26, 40, 45 of the LC / SPS Consultant Plus.
} 
Kossek E., Ozeki C. (1999) Bridging the Work-Family Policy and Productivity Gap. Community Work and Family, vol. 2, pp. 7-32.

Nilles J.M. (1975) Telecommunications and Organizational Decentralization. Transactions on Communications, vol. 23, no 10, pp. 1142-1147.

Nilles J.M., Carlson F.R., Gray P., Hanneman G.J. (1976) The Telecommunications-Transportation Tradeoff. N.Y.: Wiley, $210 \mathrm{p}$.

Nushtaikina K.V. (2013) Realization of the Employees' Right to Social Partnership for Teleworkers. Vestnik Permskogo universiteta, no 3, pp. 152-156.

Orlovskiy Yu.P. (1994) Commentarii k zakpnodatelstvy o trudovych contracrakh [Comments to the Legislation on Employment Contracts]. Moscow: Juridicheskaya Literatura, 127 p. (in Russian)

Philipova I.A. (2012) Work Books and Consequences of Their Possible Abolition. Vestnik Nizhegorodskogo universiteta, no 3, part 1, pp. 295-300.

Qvortrup L. (1998) From Telework to Networking: Definitions and Trends. In: P. Jackson, J. van der Wielen (eds.) Teleworking: International Perspectives from Telecommuting to the Virtual Organization. London: Routledge, pp. 21-39.

Sullivan C. (2003) What's in a Name? Definitions and Conceptualizations of Teleworking and Homeworking. New Technology Work and Employment, vol. 18 (3), pp. 158-165.

Siha S.M, Monroe R.W. (2006) Telecommuting's Past and Future: a Literature Review and Research Agenda. Business Process Management Journal, vol. 12, no 4, pp. 455-482.

Telework in the European Union. (2013) European Foundation for the Improvement Living and Working Conditions, pp. 19-20. Available at: http://www.eurofound.europa.eu/sites/default/files/ef_files/docs/ eiro/tn0910050s/tn0910050s.pdf (accessed: 01.03.2017)

Telework: The New Industrial Revolution? (2001). Available at: http://www.tuc.org.uk/work_life/tuc3664-f0.cfm (accessed: 01.03.2017)

Teleworking: International Perspectives. From Telecommuting to the Virtual Organization (1998). P. Jackson (ed.). N. Y.: Routledge, 368 p.

Tunnel S. (2000) Telecommuting: Homework for the Future. Journal of Computing Sciences in Colleges, vol. 15, no 3, pp. 119-127.

Visser J., Ramos Martin N. (2008) Expert Report on the Implementation of the Social Partner's Framework Agreement on Telework. Available at: https://pure.uva.nl/ws/files/1078067/79826_Telework_Report_Final.pdf (accessed: 01.03.2017) 